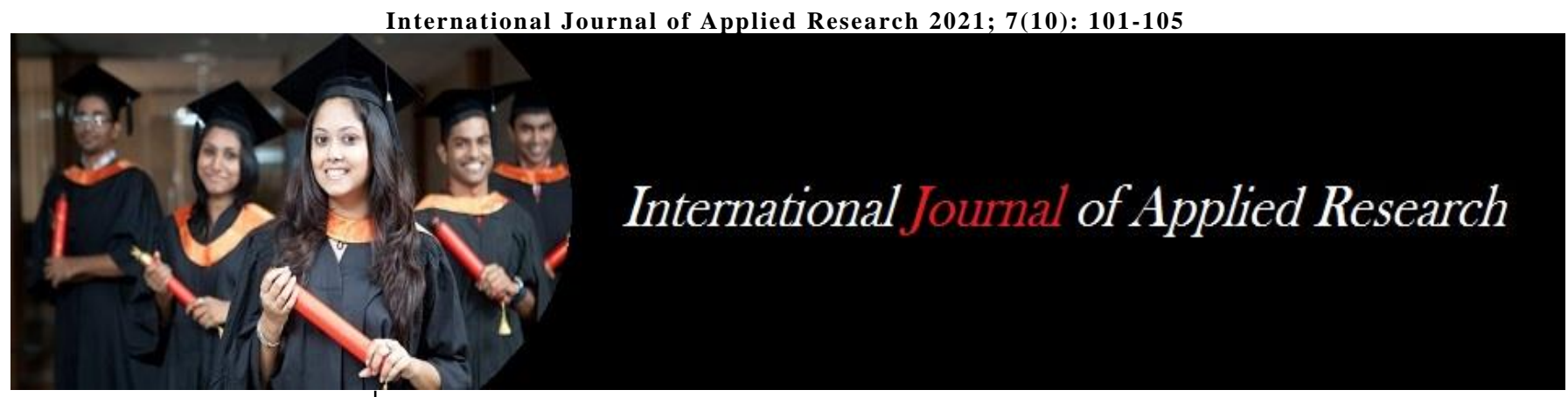

ISSN Print: 2394-7500 ISSN Online: 2394-5869 Impact Factor: 8.4 IJAR 2021; 7(10): 101-105 www.allresearchjournal.com Received: 25-08-2021 Accepted: 28-09-2021

Shivani Chauhan PG Scholar, Amity Institute of Biotechnology, Amity University Rajasthan, India

Pratik Powar

PG Scholar, Amity Institute of Biotechnology, Amity University Rajasthan, India

Rahul Mehra

Research Scholar, Amity Institute of Biotechnology, Amity University Rajasthan, Jaipur, Rajasthan, India

\section{A review on nutritional advantages and nutraceutical properties of cow and goat milk}

\author{
Shivani Chauhan, Pratik Powar and Rahul Mehra
}

DOI: https://doi.org/10.22271/allresearch.2021.v7.i10b.9025

Abstract

Milk is considered a wholesome food and is largely consumed globally. The bovine and caprine are the foremost source of milk, which also played a noteworthy role in the social-economic development of both developed and under-developed countries. The composition of milk significantly depends upon the environmental conditions, genetics, type of breed, and other internal and external factors. The protein, carbohydrate, lipid and vitamin and mineral content together makes milk into a wholesome nutritious fluid. Bovine milk is majorly consumed among milk from other species. On the other hand, the goats or caprine were the first domesticated animals by humans which also regard as "poor man cow". Milk of both varieties is highly nutritious and have potential benefits. The amount of water in the milk of both varieties is somewhat similar while on the other hand cow milk have a comparatively higher carbohydrate content than goat milk. The casein and whey protein (WPs) ratio in cow and goat milk is almost similar i.e., 80:20. Lipid content is an essential factor that regulates the physical and sensory values of milk. Goat milk is known for its better digestibility as compared to cow milk due to the existence of small-sized lipid globules. The poly-unsaturated fatty acids (PUFA) in goat milk account for their anti-cancerous properties. In the context of the bioavailability of minerals, goat milk is preferred and high levels of vitamin A is also recorded in goat milk. It has lesser content of vitamin B9, B12 and vitamin E than cow milk. Emerging evidence from the scientific research suggests that both goat and cow are comprised of an adequate number of bioactive constituents viz immunoglobins, lactoferrin, lysozyme and others that offer the medical application in the prevention and pre-treatment of numerous ailments.

Keywords: cow milk, Goat milk, composition, species, nutrition

\section{Introduction}

Cattles are the most important species in the production of milk. According to the statistics given by the National Dairy Development Board (NDDB), the annual milk supply of the world by various species are cow milk $85 \%$, buffalo milk $11 \%$, goat milk $3.4 \%$, sheep milk $1.4 \%$ and camel milk constitutes about $0.2 \%$ of the total supply (NDDB 2021.) ${ }^{[1]}$. India is the world's largest milk producer with around a 187.7 million tons of production (per capita availability of 394 grams per day). About 18 per cent of the total milk production is contributed by Uttar Pradesh making it the highest milk-producing state of India. While Rajasthan, Andhra Pradesh, Gujarat and Punjab contribute about 11\%, 10\%, $8 \%$ and $7 \%$ in India's total milk production respectively (MOFPI 2021) ${ }^{[2]}$.

Dairy based and its derivatives products play a significant role in the social-economic development for both developed and underdeveloped countries (Dogra et al. 2021) ${ }^{[3]}$. Milk is known as almost a complete food as it contains a good amount of proteins, fats and major minerals (Bhattarai 2012) ${ }^{[4]}$. Besides these nutritional components both milk sources i.e., cow and goat milk is adequate source of bioactive components viz immunoglobulins (IgG, $\operatorname{IgM}, \operatorname{IgA}$ ), lactoferrin (LF), enzymes, growth factors and hormones (Mehra et al. 2021d, c) $[5,6]$. Milk is considered as one of the principal nutritious food sources as it is linked to various health benefits like lowering body weight, blood pressure, decreasing the risk of osteoporosis, stroke and colon cancer (Kumar et al. 2014b, 2016; Turkmen 2017) ${ }^{[7-9]}$.

Milk components are responsible for providing various health benefits. Milk proteins are known to play an important role in regulating food intake, satiety and metabolic disorders
Corresponding Author: Rahul Mehra

Research Scholar, Amity Institute of Biotechnology, Amity University Rajasthan, Jaipur, Rajasthan, India 
(Bhattarai 2012; Prosser 2021; Mehra et al. 2021a) ${ }^{[4,10,11] .}$ Components in milk fat show certain functional significance while sphingolipids and their vital metabolites provide antimicrobial effects (Turck 2013) ${ }^{[12]}$. Whey proteins are also known for their health-promoting benefits like anticarcinogenic, immunostimulatory and antimicrobial activities (Deutsch 1947) ${ }^{[13]}$. The bioavailability of the trace elements is enhanced by milk protein and peptides (Fox et al. 2015) ${ }^{[14]}$. Cow's milk is known to be essential in the growth of chronic degenerative and non-communicable disorders (Kumar et al. 2014b) ${ }^{[9]}$. It is rich in protein and calcium and helps in maintaining bone health (Turck 2013) 12. Whereas goat's milk has great nutritional importance in developing and undeveloped countries (Park et al. 2007) ${ }^{[15]}$. Goat milk is an excellent source salicylic acid as compare to cow milk which played a crucial role in the brain development (Kumar et al. 2015) ${ }^{[16]}$. Goat milk also possesses some curative properties which make it advantageous in human nutrition and medicine. Both cow and goat milk vary greatly in their nutritional composition. The article highlights the key features and the differences in the biochemical composition of cow and goat milk.

\section{Composition of Milk}

Mammalian milk composition varies according to different species. The composition significantly differs due to some factors like physiological, nutritional, genetic, environmental, food composition and frequency of milking (Mehra et al. 2021d) ${ }^{[6]}$. In a study conducted by (Kalyankar et al. 2016) ${ }^{[17]}$, it was reported that the major change in composition take place during lactation The balanced nutritional composition of milk accounts for its high nutritional value making it an important component of our daily diet. Several factors influence the milk composition, the vital constituents of which are water, lipids, protein, carbohydrate, vitamins and mineral content (Mehra et al. 2021c) [5]. The gross composition of goat milk in comparison with cow milk is illustrated in Figure 1.

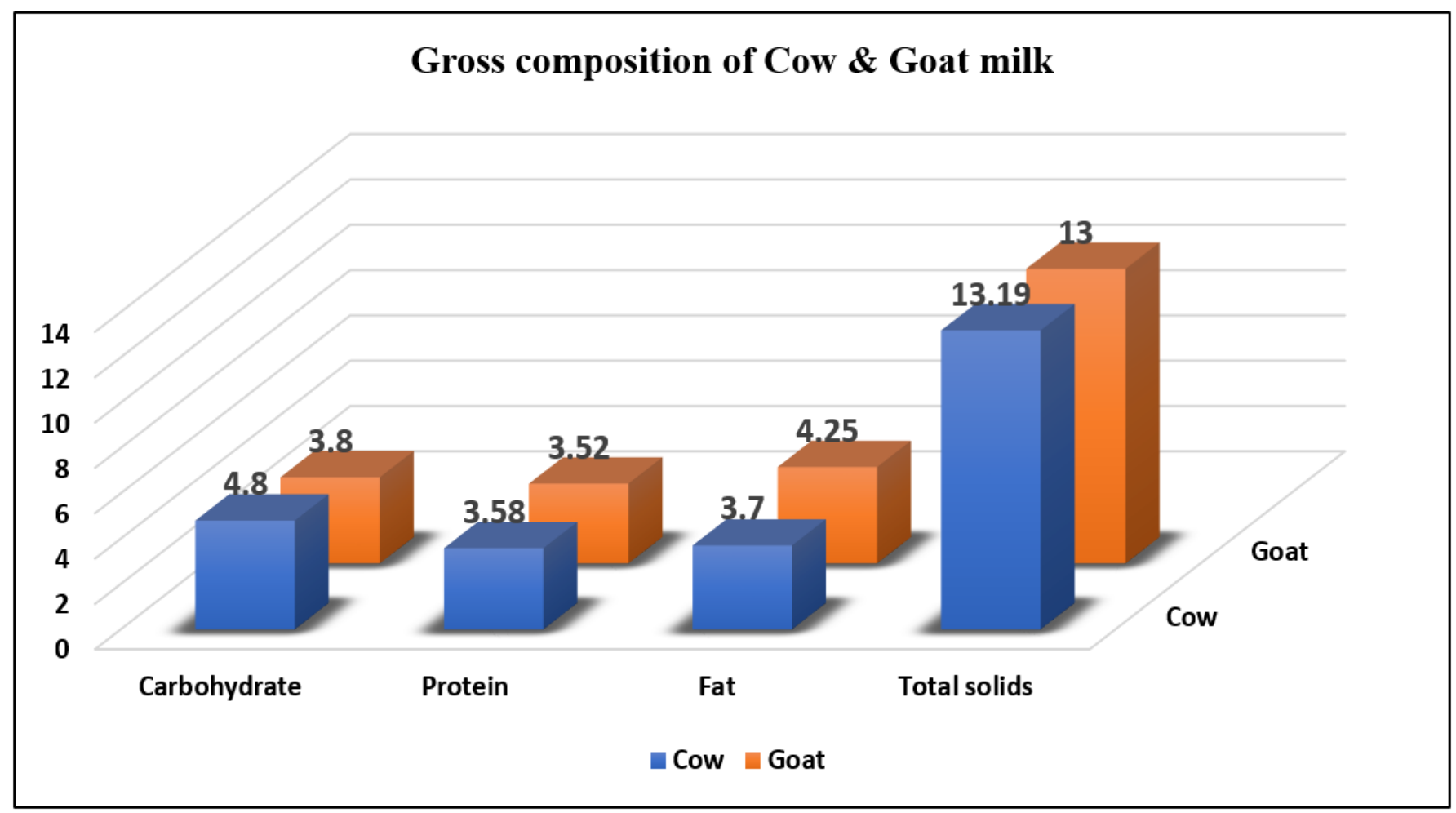

Source: $[15,18]$

Fig 1: An overview of the gross composition of goat and cow milk

\subsection{Water}

Above all the nutrients or organic substances, water forms a major part of the milk. It is observed that cow and goat milk contain approximately $86 \%$ to $88 \%$ of water. The proportion of lactose produced by the mammary glands decides the quantity of water present in milk (Kumar et al. 2016) ${ }^{[8]}$.

\subsection{Carbohydrate}

Carbohydrates are considered as fuel for the body which helps to carry out any sort of activity in the body hence, they are regarded as the cheap source of energy. Lactose forms a major part of the carbohydrate content of milk. Lactose is formed by combining 1 molecule of $\mathrm{D}$ galactose and one molecule of D-glucose. Cow milk has a comparatively higher lactose content than goat milk. It is affirmed that cow milk has $0.2-0.5 \%$ higher lactose content than goat milk.
Which states that the former having 22-27\% while 33-40\% lactose in cow milk (Park et al. 2007) ${ }^{[15]}$. Therefore, goat milk can be a convenient option for suffering from lactose intolerance. A good amount of lactose content in milk is accountable for its good taste and makes the absorption of calcium easier in the intestine. It is crucial for the bone mineralization of newborns (Yoganandi et al. 2014; Mehra et al. 2021c) ${ }^{[5,19]}$.

\subsection{Proteins}

The nutritional and bioactive compounds in milk have a crucial part in growth, development and survival especially in infants (Kumar et al. 2016; Mehra et al. 2021d) ${ }^{[6,8]}$. Amino acids are the organic molecules that makeup proteins. The amount of amino acid taurine is less in cow milk while a greater amount is seen in goat milk. The other 
free fatty acids present majorly in goat milk include glycine and glutamic acid (Yangilar 2013) ${ }^{[20]}$. Taurine in goat milk shows inhibitory action on cardiovascular disease, hypertension and also governs the synthesis of essential amino acids. It also has other benefits such as it helps in regulating blood pressure, cerebral functions, detoxification and fatty accumulation of fatty acids. In recent studies, it was observed that taurine helps in alleviating muscle fatigue and in raising workout capacity (Silanikove et al. 2010) ${ }^{[21]}$. The milk proteins are heterogenous compounds and are mainly split into major (casein) and minor (whey), thus making casein the principal milk whey protein. Approximately casein accounts for $82 \%$ of milk proteins while $18 \%$ of whey proteins are present in milk. Naturally, casein exists in four fractions namely: $\alpha s_{1}, \alpha s_{2}, \beta, K$. These fractions are distinguished based on their lower solubility at the $\mathrm{pH}$ of 4.6 and precipitation by calcium (Turck 2013; Kumar et al. 2016) ${ }^{[8,12]}$. The amount of $\mathrm{K}$ casein fraction is almost equal in the milk of both the species while in goat milk as casein is in low concentration than cow milk but a higher amount of $\beta$ casein fraction is reported in goat milk. Therefore, this makes $\alpha$ s 1 casein a major protein in milk obtained from cow and $\beta$ casein a major protein fraction in goat milk. The amount of casein in cow milk is reported as $2.46-2.80 \mathrm{~g} / 100 \mathrm{~g}$ while the amount of casein in goats is 2.81 g/100g (Leitner et al. 2004; Kumar et al. 2014b) ${ }^{[9,22]}$. Immunoglobulins which are present in whey protein are important for immune responses of the body. Whey protein in cow milk is reported between 0.55 to $0.70 \mathrm{~g} / 100 \mathrm{~g}$ while $2.81 \mathrm{~g} / 100 \mathrm{~g}$ is found in goat milk. $\alpha \mathrm{s} 1$ fraction is primarily responsible for causing milk protein allergies. Therefore, goat milk is observed to have lesser allergens thereby replacing cow milk (Kapila et al. 2013) ${ }^{[23]}$. Table 1 represent the amino acid profile in goat and cow milk.

Table 1: Amino acid profile of goat milk in comparison with cow milk

\begin{tabular}{|c|c|c|}
\hline Amino acid $(\boldsymbol{\mu M} / \mathbf{1 0 0 m l})$ & Goat & Cow \\
\hline His & 1.94 & 1.32 \\
\hline Ile & 1.64 & 1.23 \\
\hline Leu & 2.04 & 1.98 \\
\hline Lys & 3.75 & 2.65 \\
\hline Met & 0.96 & 0.85 \\
\hline Phe & 1.21 & 1.08 \\
\hline Thr & 2.78 & 2.01 \\
\hline Trp & 2.50 & 1.98 \\
\hline Val & 4.95 & 3.50 \\
\hline Asp & 1.01 & 0.98 \\
\hline Glu & 17.01 & 15.89 \\
\hline Ala & 8.68 & 5.78 \\
\hline Taurine & 55.93 & 48.23 \\
\hline
\end{tabular}

Source; (Haenlein 2004; Park 2012) ${ }^{[24,25]}$

\subsection{Lipids}

The nutritional content, physical characteristics, sensory values and cost of milk are majorly determined from its lipid content. Lipids in milk are present in the form of emulsified globules. The secretions of epithelial cells of the mammary glands form a biological coating around the fat globule (Lopez et al. 2008) ${ }^{[26]}$. This membranous coating is rich in proteins, glycoproteins, cholesterol, sphingolipids, glycerophospholipids, enzymes and other. Triglycerides represent $95 \%$ of the lipid component while phospholipids and cholesterol account for 30-40 mg and $10 \mathrm{mg}$ in $100 \mathrm{ml}$ of milk respectively. The proportions of the milk fat globule vary considerably. Goat milk fat is seen to have a higher viscosity, surface tension and specific gravity than bovine milk. The size of the bovine milk fat globule lies between 2.5 to $4.6 \mu \mathrm{m}$ in diameter (Huppertz and Kelly 2006) ${ }^{[27]}$. Goat milk has plenty of $3.5 \mu \mathrm{m}$ small-sized globules making it easier for digestibility and resulting in effective lipid metabolism than the cow milk fat (Park 2012) ${ }^{[25]}$. The cow and goat milk considerably differ in their fatty acid profile. On comparing cow and goat milk fat it is observed that fat from goat milk consists of $54.6 \%$ more caproic acid, $56.3 \%$ conjugated linoleic acid, $69.9 \%$ caprylic, and $80.2 \%$ capric and $75 \%$ less butyric acid. Goat milk comparatively accounts for the higher amount of total saturated fatty acids over cow milk, because of which milk of goat is considered right for cheese processing. It accounts for the higher concentration of short-chain fatty acids (Ceballos et al. 2009) ${ }^{[28]}$. Capric acid and caprylic acid are the short-chain fatty acid are notably present in goat milk. These are known to have a useful impact in medical treatments especially for ones suffering from metabolic disorders, cholesterol problems, malabsorption syndrome, anaemia, bone demineralization, and infant malnutrition (Kumar et al. $2014 b, 2015)^{[9,16]}$. The fatty acid profile in goat and cow milk is presented in Table 2.

Table 2: Fatty acid profile in goat and cow milk

\begin{tabular}{|c|c|c|}
\hline Fatty Acid (g/100g) & Goat Milk & Cow Milk \\
\hline Butyric & 0.13 & 3.5 \\
\hline Caproic & 0.09 & 2.3 \\
\hline Caprylic & 0.10 & 1.2 \\
\hline Capric & 0.26 & 2.6 \\
\hline Lauric & 0.12 & 2.7 \\
\hline Myristic & 0.32 & 9.3 \\
\hline Palmitic & 0.91 & 25.9 \\
\hline Stearic & 0.44 & 14.3 \\
\hline Total saturated fatty acid & 68.79 & 68.72 \\
\hline Oleic acid & 0.98 & 27.6 \\
\hline Total monounsaturated fatty acid & 24.48 & 27.40 \\
\hline Linoleic & 0.11 & 2.1 \\
\hline Linoleic & 0.04 & 0.7 \\
\hline Total Poly-unsaturated fatty acids & 3.70 & 4.05 \\
\hline
\end{tabular}

Source; (Tijerina-Sáenz et al. 2009; Tudisco et al. 2010) ${ }^{[29,30]}$

\subsection{Vitamins and minerals}

Vitamins are organic substances that are responsible for the physiological functioning and metabolic activities of the human body. Milk has water-soluble and fat-soluble vitamins which affect the fat content of dairy products. The quantity of these varies depending upon the diet of the animal and season (Mehra et al. 2021e) ${ }^{[31]}$. Vitamin A, D, E and $\mathrm{K}$ are fat-soluble, their levels increase slightly during the pasture season. The water-soluble vitamins include B group vitamins and vitamin $\mathrm{C}$ which are found in the serum. Devaki and Raveendran $2017^{[32]}$ reported that vitamin C assists in the formation of protein. Lower content of vitamin $\mathrm{A}$ is found in cow milk than in goat milk, as in goat's all $\beta$ carotene is converted to vitamin A because of which it has a whiter appearance than cow milk. Lower content of cobalamin, tocopherol and folic acid is seen in goat of milk, the deficiency of which in the human diet causes anaemia (Ljutovac et al. 2008) ${ }^{[33]}$.

Minerals play a vital role in keeping our bodies healthy. They play a major role in bone formation, enzymatic functions and oxygen transport. Milk from goats has a mineral content ranging from 0.70 to $0.85 \%$ which is higher 
than that of cow milk (Silanikove et al. 2010) ${ }^{[21]}$. Milk of goat has a good amount of $\mathrm{Ca}, \mathrm{K}, \mathrm{P}, \mathrm{Cl}, \mathrm{Se}, \mathrm{Zn}$ and $\mathrm{Cu}$ than milk from a cow. Goat milk has proved to be an important food source for people with a vegetarian diet and who depend less on meat as it has a higher content of calcium and phosphorus (Park 2012) ${ }^{[25]}$. The major difference between cow and goat milk lies in their calcium content (Mehra et al. 2020) ${ }^{[34]} .122 \mathrm{mg} / 100 \mathrm{~g} \mathrm{Ca}$ is found in cow milk while a higher amount i.e., $134 \mathrm{mg} / 100 \mathrm{~g} \mathrm{Ca}$ is found in goat milk. In the context of mineral bioavailability, goat milk is highly preferred over cow milk (Mehra et al. 2021c) [5]. The composition of vitamins and mineral in cow and goat milk is presented on Table 3 .

Table 3: Concentration of vitamin and minerals in goat and cow milk

\begin{tabular}{|c|c|c|c|c|c|}
\hline Vitamin & $\begin{array}{c}\text { Goat } \\
\text { milk }\end{array}$ & $\begin{array}{c}\text { Cow } \\
\text { milk }\end{array}$ & $\begin{array}{c}\text { Minerals } \\
(\mathbf{m g})\end{array}$ & Goat & Cow \\
\hline Retinol $(\mathrm{IU})$ & 185 & 126 & Calcium & 134 & 119 \\
\hline Calciferol $(\mathrm{IU})$ & 2.3 & 2.0 & Phosphorus & 121 & 93 \\
\hline Vitamin $\mathrm{B}_{1}(\mathrm{mg})$ & 0.048 & 0.038 & Magnesium & 16 & 13 \\
\hline Vitamin $\mathrm{B}_{2}(\mathrm{mg})$ & 0.138 & 0.162 & Potassium & 204 & 151 \\
\hline Vitamin $\mathrm{B}_{3}(\mathrm{mg})$ & 0.277 & 0.084 & Sodium & 41 & 58 \\
\hline Vitamin $\mathrm{B}_{5}(\mathrm{mg})$ & 0.31 & 0.32 & Iodine & 0.022 & 0.21 \\
\hline Pyridoxine $(\mathrm{mg})$ & 0.046 & 0.042 & Sulphur & 28 & 32 \\
\hline Ascorbic acid $(\mathrm{mg})$ & 1.29 & 0.94 & Iron & 0.05 & 0.05 \\
\hline Vitamin $\mathrm{B}_{9}(\mu \mathrm{g})$ & 1.00 & 5.00 & Copper & 0.05 & 0.06 \\
\hline Vitamin $\mathrm{B}_{7}(\mu \mathrm{g})$ & 1.5 & 2.0 & Manganese & 0.032 & 0.02 \\
\hline Cobalamin $(\mu \mathrm{g})$ & 0.065 & 0.357 & Zinc & 0.30 & 0.38 \\
\hline
\end{tabular}

Source: (Park 2012) ${ }^{[25]}$

\section{Colostrum}

The first milk secreted by the mammalian female after giving birth is termed colostrum. This milk is known to be rich in bioactive components including growth factors, immunomodulatory peptides, lactoferrin, lactoperoxidase, lysozyme and oligosaccharides. It helps in building passive immunity in newborns against pathogens. Bovine colostrum contains several immune factors which are immune globulin: G1, G2, A, M and lactoferrin out of which G1 is the prime element (Ahmad et al. 2013) ${ }^{[35]}$. Lactoferrin is a protein that helps in the binding of iron. It provides nonimmune protection and helps in regulating the absorption of iron from the gut (Giansanti et al. 2016) ${ }^{[36]}$. Bovine colostrum is known for its advantages in human health and can be taken as a dietary supplement (Mehra et al. 2021b) ${ }^{[37]}$. Studies have shown that cow colostrum has comparatively higher nutritional components than any other variety (Kumar et al. 2016) ${ }^{[8]}$. Tryptophan is an important component of bovine colostrum and plays a key role in the synthesis of protein and muscle tissue in the human body. The milk caseins are also acknowledged as the exceptional carrier of polyphenols due to the high level of proline and self-association properties (Yildirim-Elikoglu and Erdem 2018; Prabhu et al. 2021; Baniwal et al. 2021; Rudra et al. 2021) [38-41]. These polyphenols exhibits numerous therapeutic application towards human health (Kumar et al. 2014a) ${ }^{[42]}$. This essential ingredient can only be procured from a diet that is rich in tryptophan. The fat-soluble vitamins $\mathrm{A}, \mathrm{D}$ and $\mathrm{E}$ and water-soluble $\mathrm{B}$ vitamins are there in bovine colostrum which are important for metabolic processes like antioxidant activity and also in bone growth. Vitamin D supports immune functions and mental health (Cleminson et al. 2016) ${ }^{[43]}$. The transformation of colostrum to normal milk may result in a change in composition and properties (Mehra et al. 2021e) [31]. Whereas at partum goat colostrum has a higher quantity of fat, protein, SCC, lactic acid and immunity factors than the secretions during the early stages of lactation. Sialic acid in milk colostrum has proved to be an essential component because of its role in brain growth and developing immunity in newborns (Harish et al. 2015; Kumar et al. 2015) ${ }^{[16,44]}$. The percentage of sialyloligosaccharides is higher in milk from goats than cow milk (Claps et al. 2014) ${ }^{[45]}$.

\section{Conclusion}

As discussed above goat milk can be a suitable alternative for people suffering from lactose intolerance because of its lower percentage of lactose than cow milk. Thus, goat milk can be an exceptional replacement for cow milk. The protein content of both species is more or less identical. They are differentiated based on the concentration of the casein and serum protein factors. Cow milk compared to goat milk has a lower content of total saturated fatty acid because of which it is considered a suitable choice for cheese processing. Goat milk lacks in Vitamin $B_{12}$, vitamin $B_{9}$ and Vitamin $E$ which can be responsible for developing goat milk anaemia. While because of the affluent mineral content in goat milk over cow milk it is highly preferred. Several studies have shown bovine colostrum important for medicinal purposes. These studies on nutritional profiling could give a better idea for the fortification of food to deliver a wholesome product.

\section{References}

1. NDDB. Accessed September 23, 2021. https://www.nddb.coop/ccnddb/milk-facts

2. Home | Ministry of Food Processing Industries | Government of India. Accessed September 23, 2021. https://mofpi.nic.in/

3. Dogra T, Mehra R, Kumar H, Thakur M. Probiotic Potential Of Lactic Acid Bacteria Isolated From Traditional Fermented Food "Maleda" Of Northern Indian State. Ann Food Sci Technol. 2021;22(1):54-61.

4. Bhattarai RR. Importance of goat milk. J Food Sci Technol Nepal. 2012;7:107-111.

5. Mehra R, Sangwan K, Garhwal R. Composition and Therapeutic Applications of Goat Milk and Colostrum. 2021;10:1-7. doi:10.37591/rrjodst.v10i2.3163

6. Mehra R, Singh R, Nayan V et al. Nutritional Attributes of Bovine Colostrum Components in Human Health and Disease: A Comprehensive Review. Food Biosci. Published online January, 2021, 100907.

7. Turkmen N. The Nutritional Value and Health Benefits of Goat Milk Components. In: Nutrients in Dairy and Their Implications on Health and Disease. Elsevier, 2017, 441-449. doi:10.1016/B978-0-12-8097625.00035-8

8. Kumar H, Yadav D, Kumar N, Seth R, Goyal AK. Nutritional and nutraceutical properties of goat milk-a review. Indian J Dairy Sci. 2016;69:513-518.

9. Kumar H, Kumar N, Seth R, Goyal A. Chemical and immunological quality of goat colostrum: effect of breed and milking frequency. Indian $\mathrm{J}$ Dairy Sci 2014;67(6):482-486.

10. Prosser CG. Compositional and functional characteristics of goat milk and relevance as a base for infant formula. J Food Sci 2021;86(2):257-265.

11. Mehra R, Kumar H, Kumar N, Kumar S. Impact of COVID-19 Pandemic on Food Supply Chain (FSC) and 
Human Health. In: Integrated Management - Standing up for a Sustainable World. Eureka Publications, 2021, 311-319.

12. Turck D. Cow's milk and goat's milk. Evid-Based Res Pediatr Nutr. 2013;108:56-62.

13. Deutsch HF. A study of whey proteins from the milk of various animals. J Biol Chem 1947;169(2):437-448.

14. Fox PF, Uniacke-Lowe T, McSweeney PLH, O'Mahony JA. Salts of milk. In: Dairy Chemistry and Biochemistry. Springer; 2015, 241-270.

15. Park YW, Juárez M, Ramos M, Haenlein GFW. Physico-chemical characteristics of goat and sheep milk. Small Rumin Res 2007;68(1-2):88-113.

16. Kumar H, Devbrat, Kumar N, Garg V, Seth R, Kumar BSB. Sialic Acid Content in Colostrum of Two Cross Breed Dairy Goat: Effect of Breed and Lactation. J Anim Res 2015;5(4):785.

17. Kalyankar SD, Khedkar CD, Patil AM, Deosarkar SS. Milk: Sources and composition. Published online, 2016.

18. Park YW, Haenlein GFW, Wendorff WL, eds. Handbook of Milk of Non-Bovine Mammals. John Wiley \& Sons, Ltd, 2017.

19. Yoganandi J, Mehta BM, Wadhwani KN, Darji VB, Aparnathi KD. Evaluation and comparison of camel milk with cow milk and buffalo milk for gross composition. J Camel Pract Res 2014;21(2):259-265.

20. Yangilar F. As a potentially functional food: Goats' milk and products. J Food Nutr Res 2013;1(4):68-81.

21. Silanikove N, Leitner G, Merin U, Prosser CG. Recent advances in exploiting goat's milk: quality, safety and production aspects. Small Rumin Res 2010;89(23):110-124.

22. Leitner G, Chaffer M, Shamay A et al. Changes in milk composition as affected by subclinical mastitis in sheep. J Dairy Sci 2004;87(1):46-52.

23. Kapila R, Kavadi PK, Kapila S. Comparative evaluation of allergic sensitization to milk proteins of cow, buffalo and goat. Small Rumin Res 2013;112(13):191-198.

24. Haenlein GFW. Goat milk in human nutrition. Small Rumin Res 2004;51(2):155-163.

25. Park YW. Goat milk and human nutrition. In: First Asia Dairy Goat Conference 2012;9:31.

26. Lopez C, Briard-Bion V, Menard O, Rousseau F, Pradel $\mathrm{P}$, Besle J-M. Phospholipid, sphingolipid, and fatty acid compositions of the milk fat globule membrane are modified by diet. J Agric Food Chem 2008;56(13):5226-5236.

27. Huppertz T, Kelly AL. Physical chemistry of milk fat globules. In: Advanced Dairy Chemistry Volume 2 Lipids. Springer, 2006, 173-212.

28. Ceballos LS, Morales ER, de la Torre Adarve G, Castro JD, Martínez LP, Sampelayo MRS. Composition of goat and cow milk produced under similar conditions and analyzed by identical methodology. J Food Compos Anal 2009;22(4):322-329.

29. Tijerina-Sáenz A, Innis SM, Kitts DD. Antioxidant capacity of human milk and its association with vitamins $\mathrm{A}$ and $\mathrm{E}$ and fatty acid composition. Acta Paediatr. 2009;98(11):1793-1798.

30. Tudisco R, Cutrignelli MI, Calabrò S et al. Influence of organic systems on milk fatty acid profile and CLA in goats. Small Rumin Res 2010;88(2-3):151-155.
31. Mehra R, Singh R, Nayan V et al. Nutritional Attributes of Bovine Colostrum Components in Human Health and Disease: A Comprehensive Review. Food Biosci. Published online January, 2021, 100907.

32. Devaki SJ, Raveendran RL. Vitamin C: sources, functions, sensing and analysis. In: Vitamin C. IntechOpen, 2017.

33. Ljutovac KR, Lagriffoul G, Paccard P, Guillet I, Chilliard Y. Composition of goat and sheep milk products. Small Rumin Res 2008;79:57-72.

34. Mehra R, Singh R, Kumar N, Kumar S, Kumar H. Composition, Properties, and Health Attributes of Bovine Colostrum. In: Food Safety, Nutritional Security and Sustainability, 2020.

35. Ahmad S, Anjum FM, Huma N, Sameen A, Zahoor T. Composition and physico-chemical characteristics of buffalo milk with particular emphasis on lipids, proteins, minerals, enzymes and vitamins. J Anim Plant Sci. 2013;23(Suppl 1):62-74.

36. Giansanti F, Panella G, Leboffe L, Antonini G. Lactoferrin from milk: Nutraceutical and pharmacological properties. Pharmaceuticals. 2016;9(4):61.

37. Mehra R, Kumar S, Verma $\mathrm{N}$ et al. Chemometric approaches to analyze the colostrum physicochemical and immunological (IgG) properties in the recently registered Himachali Pahari cow breed in India. LWT. 2021;145:111256.

38. Yildirim-Elikoglu S, Erdem YK. Interactions between milk proteins and polyphenols: Binding mechanisms, related changes, and the future trends in the dairy industry. Food Rev Int. 2018;34(7):665-697.

39. Prabhu S, Molath A, Choksi H, Kumar S, Mehra R. Classifications of polyphenols and their potential application in human health and diseases. Int $\mathbf{J}$ Physiol Nutr Phys Educ. 2021;6(1):293-301.

40. Rudra A, Arvind I, Mehra R. Polyphenols: Types, sources and therapeutic applications. Int J Home Sci. 2021;7(3):69-75.

41. Baniwal P, Mehra R, Kumar N, Sharma S, Kumar S. Cereals: Functional constituents and its health benefits. Pharma Innov. 2021;10(3):01-07.

42. Kumar H, Choudhary N, Varsha KN, Suman SR. Phenolic compounds and their health benefits: A review. J Food Res Technol 2014;2:46-59.

43. Cleminson JS, Zalewski SP, Embleton ND. Nutrition in the preterm infant: what's new? Curr Opin Clin Nutr Metab Care 2016;19(3):220-225.

44. Harish K, Naveen K, Raman S, Arun G, Chand R. Effect of heat treatments of goat colostrum on bacterial counts, viscosity, and immunoglobulin $\mathrm{G}$ concentration. Indian J Dairy Sci 2015;68(2):132-136.

45. Claps S, Di Napoli MA, Sepe L et al. Sialyloligosaccharides content in colostrum and milk of two goat breeds. Small Rumin Res 2014;121(1):116119. 